\title{
Pembudidayaan Limbah Tandan Kosong Kelapa Sawit (TKKS) Sebagai Media Pembiakan Jamur Tiram dan Jamur Merang
}

\author{
Damris M ${ }^{1}$, Uce Lestari², Ade Adriadi3, Minarni4 \\ ${ }^{1,4}$ Program Studi Kimia Fakultas Sains dan Teknologi Universitas Jambi \\ ${ }^{2}$ Program Studi Farmasi Fakultas Kedokteran dan Ilmu Kesehatan Universitas Jambi \\ ${ }^{3}$ Program Studi Biologi Fakultas Sains dan Teknologi Universitas Jambi \\ Corresponding author: ucelestari@unja.ac.id
}

\begin{abstract}
ABSTRAK
Kelurahan Tanjung Johor merupakan kelurahan yang terletak di Kecamatan Pelayangan Kota Jambi yang merupakan salah satu desa binaan Universitas Jambi. Masyarakat Tanjung johor mayoritas bermata pencaharian sebagai petani karet dan sawit. Limbah Tandan Kosong Kelapa Sawit (TKKS) banyak sekali ditemukan diarea perkebunan kelapa sawit. Dengan melihat potensi yang ada maka muncul ide untuk memanfaatkan TKKS sebagai media pembiakan jamur tiram dan jamur merang diharapkan masalah limbah pada industri dan perkebunan kelapa sawit dapat dikurangi. Tujuan kegiatan pengabdian kepada masyarakat ini adalah membudidayakan limbah TKKS, meningkatkan pengetahuan masyarakat mengenai cara pembudidayaan limbah TKKS menjadi media pembiakan jamur dan memaksimalkan sumber daya manusia kelurahan Tanjung Johor. Metode yang digunakan dalam pelatihan ini, yaitu penyuluhan tentang manfaat limbah TKKS dan pembuatan baglog sebagai media pembiakan jamur. Kegiatan ini menghasilkan baglog atau tempat media tumbuh jamur yang dapat meningkatkan nilai jual dari jamur tiram dan jamur merang yang dihasilkan, serta meningkatkan kreativitas sumber daya manusia di Kelurahan Tanjung Johor, Kecamatan Pelayangan, Kota Jambi
\end{abstract}

Kata Kunci: Budidaya, media pembiakan, jamur

\section{PENDAHULUAN}

Kelurahan Tanjung Johor merupakan kelurahan yang terletak di Kecamatan Pelayangan, Kota Jambi yang merupakan salah satu desa binaan Universitas Jambi dan memiliki potensi sumber daya alam yang besar, namun mata pencaharian masyarakat masih mayoritas sebagai petani karet dan sawit. Belum ada yang memanfaatkan limbah TKKS sebagai media pembiakan jamur sehingga dapat menambah mata pencarian mereka. Dengan adanya potensi ini maka limbah TKKS yang berada diarea perkebunan sawit dan industri kelapa sawit dapat berkurang dengan pemanfaatannya menjadi media pembiakan jamur. Sehingga jamur tiram dan jamur merang yang dihasilkan dapat menambah nilai jual dan pendapatan bagi masyarakat disekitarnya.

Beberapa jenis jamur yang telah diuji cobakan pada media Tanda Kosong Kelapa Sawit (TKKS) antara lain jamur merang Volvariella volvacea (Siregar, 2010) dan jamur tiram Pleurotus sp. (Sudirman, et.al., 2011 dan Tabi, et.al., 2008). Hasil penelitian diatas telah menunjukkan bahwa TKKS dapat digunakan sebagai media pembiakan jamur. Berdasarkan hal diatas, maka dengan memanfaatkan TKKS sebagai media pembiakan jamur tiram dan jamur merang diharapkan masalah limbah pada perkebunan dan industri kelapa sawit dapat teratasi dan dikurangi sehingga menjadikan lingkungan bersih, indah dan sehat.

Budidaya jamur tiram dan jamur merang ini tidak memerlukan lahan yang luas 100 $\mathrm{m}^{2}$ dapat menampung \pm 7500 baglog. Produk Jamur tiram dan jamur merang yang dihasilkan dapat dimanfaatkan untuk menambah gizi serta dapat menambah pendapatan keluarga. 
Kompos bekas media tanam dapat langsung digunakan pupuk kolam ikan, makanan ikan dan untuk memelihara cacing. Budidaya jamur tiram dan merang mempunyai waktu panen yang singkat 1,5 bulan sudah memetik hasil, tidak membutuhkan biaya pakan, obat-obatan, dan pupuk (Manuell,1995, Meinanda, 2013)

Jamur di pasaran banyak dicari oleh masyarakat, karena jamur sebagai bahan pangan yang banyak dikonsumsi, cita rasa yang lezat, bergizi tinggi dan sebagai bahan pangan fungsional serta mampu menurunkan kolesterol, gula darah dan juga kanker (Meinanda, 2013).

Jamur tiram banyak mengandung protein nabati 10-30\%, lemak, fosfor, besi, thiamine dan riboflavin lebih tinggi dibandingkan dengan jenis jamur lain. Jamur tiram mudah dikembangkan,media tumbuh \& bahan spora mudah didapat, dan harga jual cukup tinggi. Sedangkan Jamur Merang (Volvariella volvaceae) banyak ditemukan ditumpukan jerami atau pada saat musim panen padi. Jamur merang memiliki cita rasa yang nikmat dan kandungan gizi yang cukup baik untuk kesehatan, sehingga menjadi alternatif sebagai bahan pangan (Ningtyas, 2010)

Hasil pembinaan dan kerja sama dari dosen Universitas Jambi seperti pembudidayaan limbah TKKS sebagai media pembiakan jamur tiram dan jamur merang, namun sebelumnya masyarakat Tanjung Johor belum membudidayakan jamur tiram dan jamur merang.

Tujuan kegiatan pengabdian kepada masyarakat ini adalah mampu memberi mengurangi limbah TKKS disekitar perkebunan kelapa sawit, meningkatkan nilai jual jamur tiram dan jamur merang hasil pertanian, meningkatkan pengetahuan masyarakat mengenai manfaat jamur tiram dan jamur merang, dan memaksimalkan sumber daya manusia kelurahan Tanjung Johor. Metode yang digunakan dalam pelatihan ini, yaitu penyuluhan tentang manfaat jamur tiram dan jamur merang dan pembuatan baglog dengan media TKKS. Kegiatan ini menghasilkan baglog dengab media TKKS yang dapat meningkatkan nilai jual dari jamur tiram dan jamur merang serta meningkatkan kreativitas sumber daya manusia di Kelurahan Tanjung Johor, Kecamatan Pelayangan, Kota Jambi.

\section{METODE PELAKSANAAN}

\section{Waktu dan Tempat}

Pelatihan ini telah dilaksanakan pada hari sabtu tanggal 22 Agustus 2020 di salah satu rumah masyarakat kelurahan Tanjung Johor, Kecamatan Pelayangan, Kota Jambi.

\section{Alat dan Bahan}

Adapun bahan yang digunakan dalam kegiatan pelatihan ini adalah Bibit jamur tiram, tandan sawit kosong, bekatul (dedak), Dolomit. Alat yang digunakan adalah

Mixer, cangkul, sekop, filler, botol, boiler, gerobak dorong, sendok, bibit, kantong plastik, karet, kapas, cincin plastik dan centong.

\section{Prosedur Kerja}

Berikut adalah program kerja yang dilaksanakan dalam kegiatan pengabdian kepada masyarakat ini: 1) Memberikan penyuluhan kepada masyarakat tentang manfaat limbah TKKS sebagai media pembiakan jamur tiram dan jamur merang.2) Memberikan penyuluhan kepada masyarakat tentang pembuatan baglog media TKKS.

\section{Penyuluhan Teknologi Budidaya Jamur Tiram dan Jamur Merang}

Budidaya jamur tiram dan jamur merang ini tidak memerlukan lahan yang luas $100 \mathrm{~m} 2$ dapat menampung \pm 7500 baglog. Produk Jamur tiram dan jamur merang yang dihasilkan dapat dimanfaatkan untuk menambah gizi serta dapat menambah pendapatan keluarga. Kompos 
bekas media tanam dapat langsung digunakan pupuk kolam ikan, makanan ikan dan untuk memelihara cacing. Budidaya jamur tiram dan merang mempunyai waktu panen yang singkat 1,5 bulan sudah memetik hasil, tidak membutuhkan biaya pakan, obat-obatan, dan pupuk (Meinanda,2013).

\section{Persiapan Budidaya Jamur Tiram dan Jamur Merang}

Adapun tahapan awal yang dilakukan untuk budidaya jamur tiram dan jamur merang adalah pembuatan Kumbung. Kumbung adalah rumah dimana jamur tumbuh dan berkembang lalu dipetik. Kumbung berukuran 4 × $6 \mathrm{~m} 2$ dengan 5 rak didalamnya, jarak setiap rak berkisar 75 $\mathrm{cm}$. Atap kumbung menggunakan daun nipah atau jerami padi untuk menjaga kestabilan kelembaban udara didalam ruangan. Dinding kumbung harus menggunakan plastik putih dan bagian luar dengan plastic hitam agar cahaya matahari tidak menembus kedalam ruangan secara langsung. Lantai tanah agar menjaga kelembaban udara . Ada ventilasi udara untuk mengatur suhu kumbung dengan membuat jendela di bagian atas depan dan belakang kumbung Serta pintu masuk didepan. Kumpung bertahan selama 3 tahun (Alawiah, 2008; Dahyar,2010)

\section{Pembuatan Media Jamur Tiram dan Jamur Merang}

Media tanam jamur tiram dan jamur merang menggunakan TKKS. Satu kumbung jamur 1 mobil truck ukuran kecil. TKKS yang masih baru dan panas harus dibiarkan beberapa hari terlebih dahulu hingga membususk sebelum dilakukan pengolahan dan pengomposan. Jika TKKS sudah cukup membusuk, maka TKKS sudah siap untuk diberikan beberapa perlakuan sebagai berikut (Jumriah,2016;Kartika et all 1997):

\section{Perendaman}

Perendaman TKKS dilakukan didalam kolam dengan ukuran sesuai, hal ini dilakukan untuk menjaga kualitas TKKS agar bisa serentak dalam melakukan tahap pengomposan. Perendaman berfungsi sebagai pemudahan media untuk difermentasi karena media yang lembab. Lamanya waktu perendaman adalah satu hari satu malam.

\section{Pengomposan}

Pengomposan ialah memberikan nutrisi dan menetralisir media sebelum difermentasi. Dalam pengomposan ini, dibutuhkan dedak 20\%, Dolomit 3\% dan Air 70\%. Dolomit sebagai penetralisir $\mathrm{pH}$ pada media dan dedak sebagai penutrisi. Pengomposan harus dilakukan secara merata dan menyeluruh. Dimasukkan kedalam baglog.

\section{Sterilisasi}

Sterilisasi dilakukan dengan mempergunakan alat sterilizer yang bertujuan menginaktifkan mikroba, bakteri, kapang, maupun khamir yang dapat mengganggu pertumbuhan jamur yang ditanam. Sterilisasi dilakukan pada suhu $90-100$ derajat $C$ selama 12 jam.

\section{Inokulasi (Penanaman Bibit)}

Baglog ditiriskan selama 1 malam setelah sterilisasi, kemudian kita ambil dan ditanami bibit diatasnya dengan mempergunakan sendok makan/sendok bibit sekitar +3 sendok makan kemudian diikat dengan karet \& ditutup dengan kapas. Bibit Jamur yang baik yaitu: varitas unggul, umur bibit optimal 45 - 60 hari, warna bibit merata dan tidak terkontaminasi

\section{Penumbuhan Tubuh Buah}

Inkubasi (masa pertumbuhan miselium); bertujuan untuk menumbuhkan miselium jamur pada media tanam yang sudah diinokulasi bibit jamur tiram (Spawning). Kondisi ruangan diatur pada suhu 22 - 28 derajat $\mathrm{C}$ dengan kelembaban $60 \%$ - 80\%. Ruangan ini dilengkapi dengan 
rak-rak bambu untuk menempatkan media tanam dalam kantong plastik (baglog) yang sudah diinokulasi.

\section{Panen}

Panen dilakukan setelah pertumbuhan jamur mencapai tingkat yang optimal,pemanenan biasanya dilakukan 5 hari setelah tumbuh calon jamur. Pemanenan sebaiknya dilakukan pada pagi hari untuk mempertahankan kesegarannya \& mempermudah pemasaran. Lebih baik tidak menggunakan kuku tangan, tetapi menggunakan pisau yang telah disterilkan. Tinggalkan / sisakan sedikit pangkal buah jamur yang di panen. Media tidak boleh terangkat.

\section{HASIL DAN PEMBAHASAN}

Hasil yang dicapai dalam kegiatan pengabdian kepada masyarakat ini adalah terlaksananya pelatihan pembuatan media pembiakan jamur tiram dan jamur merang dari limbah TKKS yang memberikan pengetahuan dan skill bagi masyarakat Tanjung Johor tentang pemanfaatan limbah TKKS disekitar perkebunan kelapa sawit. .

Kegiatan ini sudah melakukan koordinasi awal dengan ibu RT 04 Kelurahan Tanjung Johor, kecamatan Pelayangan, Kota Jambi dan telah mendapatkan izin rekomendasi untuk mengadakan pelatihan dari tim gugus covid 19 dan camat Pelayangan, dikarenakan kegiatan PPM ini diadakan pada saat pandemi covid 19 dengan ketentian mengikuti protokol kesehatan pada pelaksanaanya.

Hasil kesepakatan dengan ibu RT setempat dihasilkan rencana kegiatan pelatihan kepada masyarakatan kelurahan Tanjung Johor RT 04 berdasarkan kebutuhan untuk pembuatan media jamur tiram dan jamur merang dari limbah TKKS. Hasil kegiatan wawancara dan diskusi awal bahwa masyarakat Tanjung Johor belum memanfaatkan limbah TKKS yang hanya terbuang dan membusuk sekitar perkebunan sawit .

Kegiatan penyuluhan kepada masyarakat Tanjung Johor dilakukan setelah adanya survei awal. Adapun peserta penyuluhan disiapkan oleh pihak kelurahan yang merupakan warga sekitar. Dalam pelaksanaan kegiatan ini masyarakat sangat antusias mengikuti pelatihan dan penyuluhan mengenai pembuatan media jamur tiram dan jamur merang dari limbah TKKS seperti ditunjukkan pada Gambar 1.
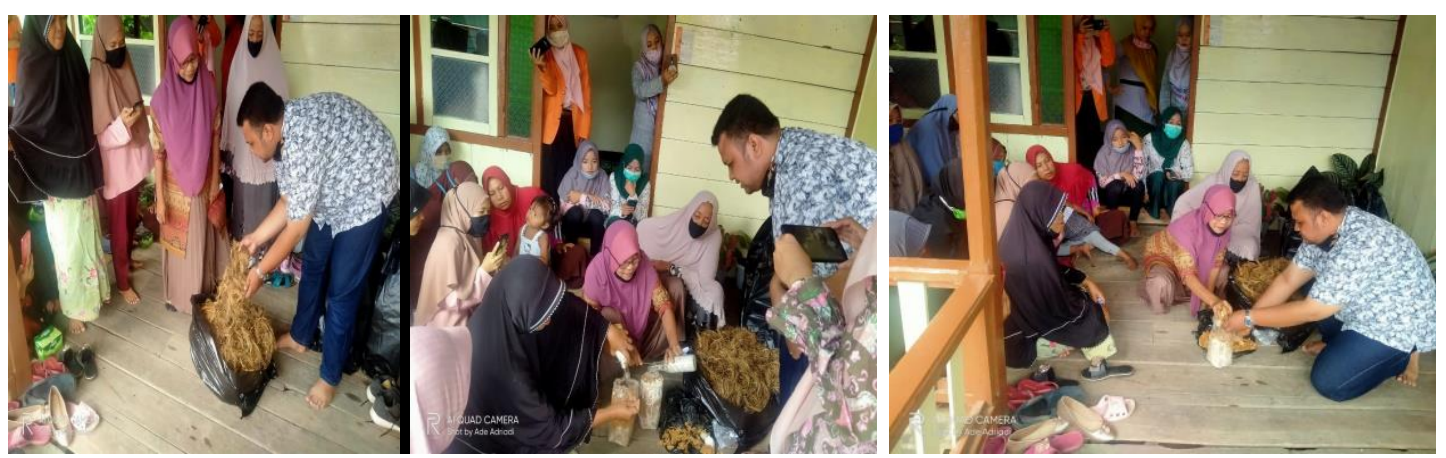

Gambar 1. Pelatihan pembuatan media jamur tiram dan jamur merang

Hasil kegiatan pelatihan dan penyuluhan ini memberikan masyarakat pengetahuan lebih tentang pemanfaatan limbah TKKS sebagai media pembiakan jamur tiram dan jamur merang sehingga dapat meningkatkan minat masyarakat terhadap membuka usaha pertanian jamur tiram dan jamur merang. 


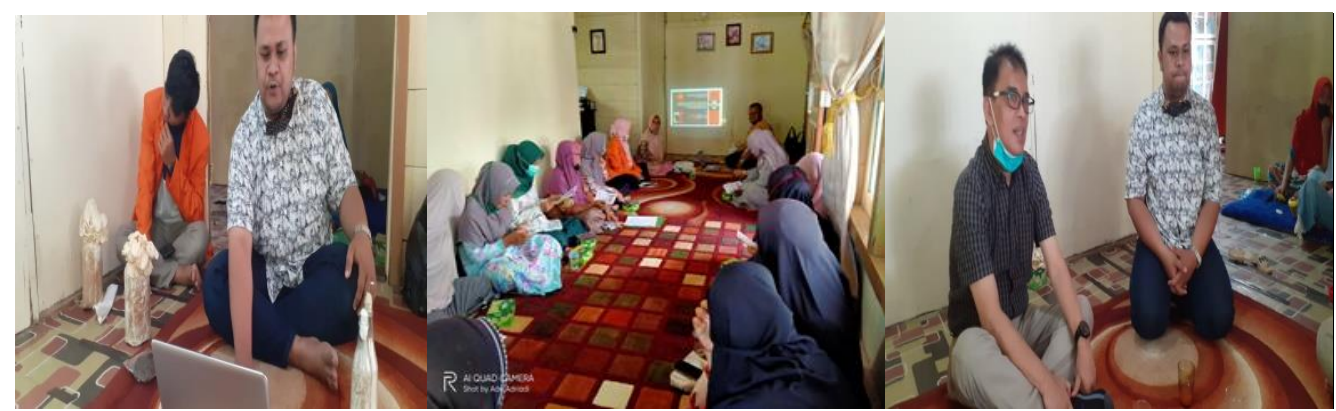

Gambar 2. Penyuluhan budidaya jamur

Tim PPM Desa Binaan Universitas Jambi kami bersama dengan petani kelapa sawit Kelurahan Tanjung Johor akan melakukan diversifikasi pangan untuk meningkatkan nilai jual dari jamur tiram dan jamur merang dengan pembentukan usaha budidaya jamur sehingga dapat meningkatan pendapatan dan memperluas lapangan pekerjaan bagi masyarakat Tanjung Johor dan tidak hanya sebagai petani karet dan sawit saja.

Diakhir acara dilakukan foto bersama bersama tim PPM Desa Binaan Universitas Jambi dengan peseta penyuluhan masyarakat Tanjung Johor.

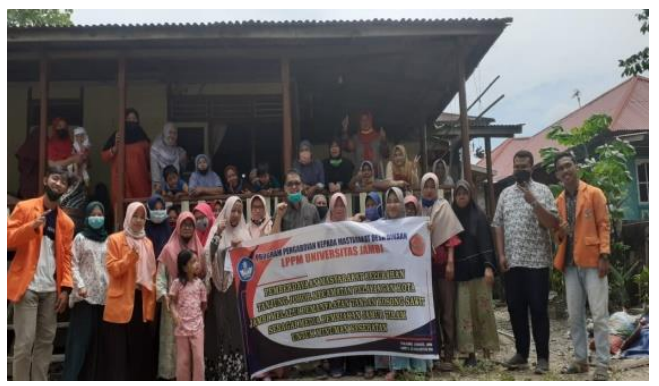

Gambar 3. Foto Bersama

\section{KESIMPULAN}

Hasil dari kegiatan pelatihan pembudidayaan jamur tiram dan jamur merang dari limbah TKKS dapat disimpulkan bahwa kegiatan ini memberikan pengetahuan lebih tentang manfaat limbah TKKS sebagai media pembiakan jamur. Selain itu dapat meningkatkan daya jual jamur tiram dan jamur merang dalam usaha budidaya ini. Dengan adanya kegiatan pelatihan ini juga meningkatkan kreativitas sumber daya di Kelurahan Tanjung Johor.

\section{UCAPAN TERIMAKASIH}

Terima kasih untuk pihak yang telah membantu baik dana ataupun support terutama pihak Lurah Tanjung Johor, Camat Pelayangan, RT 04 Kelurahan Tanjung Johor dan Rektor Universitas Jambi, LPPM Universitas Jambi dan semua pihak yang terkait sehingga pelaksanaan PPM ini terlaksana dengan baik dan lancar.

\section{DAFTAR PUSTAKA}

Alwiah. (2008). Pertumbuhan dan perkembangan Pleurotus sp. pada media serbuk gergajian kayu sengon (Paraserianthes falcataria). Skripsi. Fakultas Kehutanan. Institut Pertanian Bogor.

Dahyar, A. (2010). Pemanfaatan Limbah Tandan Kosong Kelapa Sawit dan Azola Menjadi Kompos Pupuk Tablet. Tesis. Sekolah Pasca Sarjana. Universitas Sumatera Utara, Sumatera Utara. 
Jumbriah. (2006). Bioremediasi Tanah Tercemar Diazinon Secara Ex Situ dengan Menggunakan Kompos Limbah Media Jamur (Spent Mushroom Compost). Tesis. Sekolah Pascasarjana. Institut Pertanian Bogor, Bogor.

Kartika, L., Pudyastuti, Y.M. \& Gunawan, A.W. (1995). Campuran Serbuk Gergaji Kayu Sengon dan Tongkol Jagung sebagai Media untuk Budi Daya Jamur Tiram Putih. Hayati. 2(1), 23-27.

Manuella, M. \& Gunawan, D.A.W. (1997). Pertumbuhan Panus sp. pada Media

Tandan Kosong Kelapa Sawit. Hayati. 4(2), 51-52. Meinanda, I. (2013). Panen Cepat Budidaya Jamur. Padi: Bandung.

Ningtyas, V.A. \& Astuti, L.Y. (2010). Pemanfaatan Tandan Kosong Kelapa Sawit Sisa Media Jamur Merang (Volvariella volvacea) sebagai Pupuk Organik dengan Penambahan Aktivator Effective Microorganism EM-4. Skripsi. Fakultas Teknik. Institut Teknologi Sepuluh Nopember, Surabaya.

Siregar, H.J. (2010). Pertumbuhan dan Produksi Jamur Merang (Volvariella volvaceae) pada Media Tandan Kosong Kelapa Sawit dengan Waktu Fermentasi yang Berbeda. Skripsi. Fakultas Pertanian, Universitas Sumatera Utara, Sumatera Utara.

Sudirman, L.I, Sutrisna, A., Listiyowati, S., Fadli, L. \& Tarigan, B.A.L.A.M.A.N. (2011). The Potency of Oil Palm Plantation Wastes for Mushroom Production. In Proceedings of the 7th International Conference on Mushroom Biology and Mushroom Products (pp. 383389). France.

Sudiyani, Y., Heru, R. \& Alawiyah, S. (2010).Pemanfaatan Biomassa Limbah Lignoselulosa untuk Bioetanol sebagai Sumber Energi Baru Terbarukan. Ecolab. 4(1), 1-54.

Tabi, M., Nafissa, A., Ahmad, Z.F., fauzai, M., Fauzan, W.N., Ali, N. \& Hassan, O. (2008). The Usage of Empty Fruit Bunch (EFB) and Palm Pressed Fibre (PPF) as Substrates for the Cultivation of Pleurotus ostreatus. Jurnal Teknologi. (49), 189-196. 